\title{
Water Resistance and Creep Behavior of Heat-Treated Moso Bamboo Determined by the Stepped Isostress Method
}

\author{
Teng-Chun Yang ${ }^{1, *}$, Tung-Lin $\mathrm{Wu}^{2}$ and Chin-Hao Yeh ${ }^{1}$ \\ 1 Department of Forestry, National Chung Hsing University, Taichung 402, Taiwan; \\ harrison19960219@gmail.com \\ 2 Department of Wood Science and Design, National Pingtung University of Science and Technology, \\ Pingtung 912, Taiwan; tonywu@mail.npust.edu.tw \\ * Correspondence: tcyang.04@nchu.edu.tw
}

check for updates

Citation: Yang, T.-C.; Wu, T.-L.; Yeh, C.-H. Water Resistance and Creep Behavior of Heat-Treated Moso Bamboo Determined by the Stepped Isostress Method. Polymers 2021, 13 1264. https://doi.org/10.3390/ polym 13081264

Academic Editor: Eric Pollet

Received: 23 March 2021

Accepted: 10 April 2021

Published: 13 April 2021

Publisher's Note: MDPI stays neutral with regard to jurisdictional claims in published maps and institutional affiliations.

Copyright: (C) 2021 by the authors. Licensee MDPI, Basel, Switzerland. This article is an open access article distributed under the terms and conditions of the Creative Commons Attribution (CC BY) license (https:/ / creativecommons.org/licenses/by/ $4.0 /)$.

\begin{abstract}
The influence of heat treatment on the physico-mechanical properties, water resistance, and creep behavior of moso bamboo (Phyllostachys pubescens) was determined in this study. The results revealed that the density, moisture content, and flexural properties showed negative relationships with the heat treatment temperature, while an improvement in the dimensional stability (anti-swelling efficiency and anti-water absorption efficiency) of heat-treated samples was observed during water absorption tests. Additionally, the creep master curves of the untreated and heat-treated samples were successfully constructed using the stepped isostress method (SSM) at a series of elevated stresses. Furthermore, the SSM-predicted creep compliance curves fit well with the 90-day full-scale experimental data. When the heat treatment temperature increased to $180^{\circ} \mathrm{C}$, the degradation ratio of the creep resistance $\left(r_{\mathrm{d}}\right)$ significantly increased over all periods. However, the $r_{\mathrm{d}}$ of the tested bamboo decreased as the heat treatment temperature increased up to $220{ }^{\circ} \mathrm{C}$.
\end{abstract}

Keywords: moso bamboo; heat treatment; water resistance; creep behavior; stepped isostress method (SSM)

\section{Introduction}

Bamboo has been of interest in academia and industry as a natural resource due to its fast growth rate compared to other plants and because it is an eco-friendly and renewable material. Recently, bamboo-based products, such as reconstituted densified bamboo boards [1-3], laminated bamboo lumber [4,5], and bamboo fiber-reinforced polymer composites [6,7], have been increasingly developed in various regions. However, bamboo has a high hygroscopicity and low biological durability since it is a lignocellulosic material. To resolve these drawbacks, heat treatment, which is a physical and eco-friendly modification, has been considered in the bamboo-based product industry. Several previous studies have treated the bamboo under various temperatures, durations, and media (air, nitrogen, oil, and steam) [8-11]. The findings of these studies indicated that heat treatment decreases the hygroscopicity of bamboo and improves its dimensional stability, but it reduces the mechanical properties. Yang et al. [8] reported that the moisture content, density, and flexural properties decreased, and moisture-excluding efficiencies and anti-shrinking of bamboo improved as the treatment temperature increased. Zhang et al. [9] stated that the contents of the chemical components (holocellulose and $\alpha$-cellulose) and the modulus of rupture (MOR) reduced with the increase in temperature and duration when bamboo was treated above $160^{\circ} \mathrm{C}$. Yang et al. [10] investigated and observed that the bamboo treated at a higher temperature had a high thermal stability and Poisson's ratio, an increase in cellulose crystallinity, hemicellulose deacetylation, and cross-linking of lignin condensation. Additionally, Marasigan et al. [12] explored that heat treatment caused a change in the surface color and an improvement in the wettability property of two bamboo species in Philippines. Brito et al. [13] affirmed that heat treatment improved biological resistance of 
bamboo to brown rot fungi, but not to termites. These previous studies mainly focused on physico-mechanical properties and biological durability of the heat-treated bamboo. However, the available information on the creep behaviors of the heat-treated bamboo lacks detail.

The phenomenon of creep is the permanent inelastic deformation of a material caused by a sustained applied load and affects serviceability. Additionally, creep has the ability to change the characteristics of a structural element or system, possibly resulting in structural failure. Therefore, creep behavior is one of the critical issues in the structural design of materials, particularly anisotropic materials. A few previous studies investigated the creep of untreated bamboo [14-16]. However, the available information on the creep of heattreated bamboo lacks detail. Generally, a long-term and full-scale creep test is conducted to estimate the service life of a material, but it is prohibitively expensive and time-consuming. Therefore, an accelerated creep test based on the stepped isostress method (SSM) has been developed to reduce the test time and to predict the full-scale creep of a material. Previous studies $[17,18]$ have reported that the SSM could successfully evaluate the creep behavior of various materials, such as wood and wood-based products. However, there is little information available on the creep properties of heat-treated bamboo samples. Accordingly, the present study aims to investigate the effects of heat treatment on the dimensional stability of moso bamboo after a water absorption test and to determine its creep resistance with the SSM.

\section{Materials and Methods}

\subsection{Materials and Heat Treatment Process}

The middle section of a three-year-old moso bamboo (Phyllostachys pubescens) culm was purchased from a local factory in Nan-Tou County, Taiwan. The bamboo culm was split and peeled to obtain bamboo strips with dimensions of $120 \mathrm{~mm}(\mathrm{~L}) \times 8 \mathrm{~mm}(T) \times 5 \mathrm{~mm}(R)$. The density of all the samples selected was in the range of 700 to $750 \mathrm{~kg} / \mathrm{m}^{3}$. For heat treatment, the samples were heated at $180^{\circ} \mathrm{C}$ and $220^{\circ} \mathrm{C}$ for $2 \mathrm{~h}$ under nitrogen at atmospheric pressure in a conventional oven (JB-27, ProKao Instrument Co., Taichung, Taiwan). Additionally, the untreated sample and samples heat-treated at $180^{\circ} \mathrm{C}$ and $220^{\circ} \mathrm{C}$ were denoted as $\mathrm{Mo}_{\mathrm{NT}}, \mathrm{Mo}_{\mathrm{T} 180}$, and $\mathrm{Mo}_{\mathrm{T} 220}$, respectively. Prior to testing, all the samples were conditioned at $25^{\circ} \mathrm{C}$ and $65 \%$ relative humidity (RH) for 4 weeks.

\subsection{Physical and Flexural Properties}

\subsubsection{Density}

The density $(\rho)$ of a sample before and after heat treatment and the loss rate in the density $(D L R)$ were calculated as

$$
\begin{gathered}
\rho\left(\mathrm{kg} / \mathrm{m}^{3}\right)=m / v \\
\operatorname{DLR}(\%)=\left(\rho_{\mathrm{N}}-\rho_{\mathrm{h}}\right) / \rho_{\mathrm{N}} \times 100
\end{gathered}
$$

where $m$ and $v$ are the mass and volume of the sample, respectively, and $\rho_{\mathrm{N}}$ and $\rho_{\mathrm{h}}$ are the densities of the sample before and after heat treatment, respectively.

\subsubsection{Moisture Content}

The moisture content $(M C)$ of the sample before and after heat treatment and the loss rate in the moisture content $(M L R)$ were determined as

$$
\begin{gathered}
M C(\%)=\left(m_{\mathrm{u}}-m_{\mathrm{o}}\right) / m_{\mathrm{o}} \times 100 \\
\operatorname{MLR}(\%)=\left(M C_{\mathrm{N}}-M C_{\mathrm{h}}\right) / M C_{\mathrm{N}} \times 100
\end{gathered}
$$


where $m_{\mathbf{u}}$ and $m_{\mathrm{o}}$ are the masses of the sample after conditioning and oven-drying, and $M C_{\mathrm{N}}$ and $M C_{\mathrm{h}}$ are the moisture content of the sample before and after heat treatment.

\subsubsection{Flexural Properties}

The samples with an outer layer on the tension side were tested in a three-point flexural test at a span of $84 \mathrm{~mm}$ and a crosshead speed of $2 \mathrm{~mm} / \mathrm{min}$. The modulus of rupture (MOR), modulus of elasticity (MOE), and strain at ultimate load $\left(\varepsilon_{\mathrm{u}}\right)$ were assessed with the following equations:

$$
\begin{aligned}
\operatorname{MOR}(\mathrm{MPa}) & =3 P_{\mathrm{u}} L /\left(2 b h^{2}\right) \\
\operatorname{MOE}(\mathrm{MPa}) & =P_{\mathrm{p}} L^{3} /\left(4 \delta b h^{3}\right) \\
\varepsilon_{\mathrm{u}}(\%) & =6 D h / L^{2}
\end{aligned}
$$

where $P_{\mathrm{u}}$ is the ultimate load $(\mathrm{N}), L$ is the span of the sample $(\mathrm{mm}), b$ is the width of the sample $(\mathrm{mm}), h$ is the thickness of the sample $(\mathrm{mm}), P_{\mathrm{p}}$ is the load difference within the proportional limit $(\mathrm{N}), \delta$ is the deflection at the midspan under $P_{\mathrm{p}}(\mathrm{mm})$, and $D$ is the deflection under $P_{\mathrm{u}}(\mathrm{mm})$.

\subsubsection{Water Absorption Test}

Before testing, all the samples were previously oven-dried at $105^{\circ} \mathrm{C}$. Afterward, the samples were fully immersed in water at $20^{\circ} \mathrm{C}$ for $24 \mathrm{~h}$, and the weight and volume were then measured. According to ASTM D1037-12, the water absorption rate (WAR) and volume swelling coefficient (VSC) of untreated and heat-treated samples were determined using the following equations:

$$
\begin{gathered}
\operatorname{WAR}(\%)=\left(W_{\mathrm{w}}-W_{\mathrm{o}}\right) / W_{\mathrm{o}} \times 100 \\
\operatorname{VSC}(\%)=\left(V_{\mathrm{w}}-V_{\mathrm{o}}\right) / V_{\mathrm{o}} \times 100
\end{gathered}
$$

where $W_{\mathrm{w}}$ and $V_{\mathrm{w}}$ are the weight and volume of the sample after immersion in water, and $W_{\mathrm{o}}$ and $V_{\mathrm{o}}$ are the weight and volume of the sample after oven-drying. Furthermore, the anti-swelling efficiency ( $A S E)$ and anti-water absorption efficiency ( $A W A E$ ) were calculated as

$$
\begin{aligned}
A S E(\%) & =\left(V S C_{\mathrm{N}}-V S C_{\mathrm{h}}\right) / V S C_{\mathrm{N}} \times 100 \\
A W A E(\%) & =\left(W A R_{\mathrm{N}}-W A R_{\mathrm{h}}\right) / W A R_{\mathrm{N}} \times 100
\end{aligned}
$$

where $V S C_{\mathrm{N}}$ and $W A R_{\mathrm{N}}$ are the $V S C$ and $W A R$ of the sample before heat treatment, and $V S C_{\mathrm{h}}$ and $W A R_{\mathrm{h}}$ are the $V S C$ and $W A R$ of the sample after heat treatment.

\subsection{Creep Test}

A conventional experimental creep test was implemented to serve as a basis for comparison with an accelerated creep test using the SSM, as shown in Figure 1a. The sustained stress was $20 \%$ of the average breaking load (ABL) for a period of 90 days. The vertical deflection at the midspan was recorded using a linear variable differential transducer (LVDT). Three samples of each bamboo treatment were tested. 
(a)

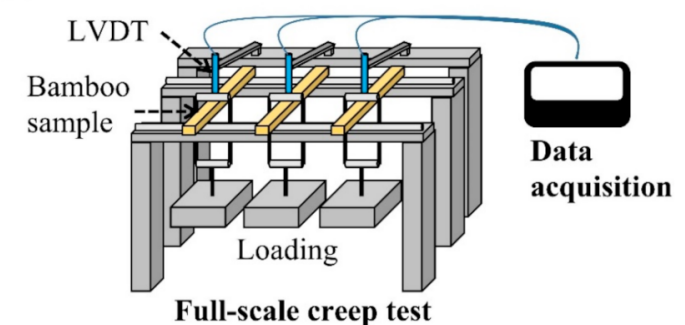

(b)

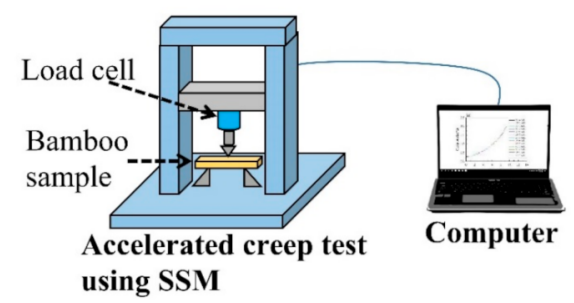

Figure 1. Schematic diagrams of the full-scale creep test (a) and accelerated creep test using SSM (b).

The SSM was implemented using a universal testing machine (Shimadzu AG-10kNX, Tokyo, Japan) equipped to predict the long-term and full-scale experimental creep behavior of untreated and heat-treated bamboo samples (Figure 1b). To investigate the SSM creep tests using various testing parameters, a creep test following the SSM was conducted using a series of isostresses from $20 \%$ to $80 \% \mathrm{ABL}$, with intervals of $5 \%, 7.5 \%$, and $10 \% \mathrm{ABL}$. The reference stress and the dwell time for each isostress were $20 \%$ ABL and $2 \mathrm{~h}$, respectively. A master curve, which involves the creep strain at a reference stress and shifting the timescale of the measured creep curves, was constructed with the SSM data and Equation (12):

$$
\varepsilon\left(\sigma_{\mathrm{r}}, t\right)=\varepsilon\left(\sigma, t / \alpha_{\sigma}\right)
$$

where $\varepsilon$ is the creep strain as a function of stress and time, $\sigma_{\mathrm{r}}$ is the reference stress, $\sigma$ is the elevated stress, and $\alpha_{\sigma}$ is the shift factor. Additionally, the activation volume was calculated to estimate the shift factor $\left(\alpha_{\sigma}\right)$ based on the Eyring model, which describes the creep rate with the stress level $[19,20]$ :

$$
\log \alpha_{\sigma}=\log \left(\frac{\dot{\varepsilon}}{\dot{\varepsilon}_{\mathrm{r}}}\right)=\frac{V *}{2.30 k T}\left(\sigma-\sigma_{\text {ref }}\right)
$$

where $\dot{\varepsilon}$ is the creep rate at the elevated stress $(\sigma), \dot{\varepsilon}_{\mathrm{r}}$ is the creep rate at the reference stress $\left(\sigma_{\text {ref }}\right), V^{*}$ is the activation volume, $k$ is Boltzmann's constant, and $T$ is the absolute temperature. Furthermore, the creep compliance $(J(t))$ was calculated to estimate the creep behavior of the samples due to the changes in the flexural strength among all the samples and is given in Equation (14) [21]:

$$
J(t)=D(t)\left(4 b h^{3} / P L^{3}\right)
$$

where $D(t)$ is the time-dependent deflection, $b$ is the width of the sample, $h$ is the thickness of the sample, $t$ is the elapsed time, $P$ is the applied load, and $L$ is the length of the span. All the samples were held at $25^{\circ} \mathrm{C}$ and $65 \%$ RH during the accelerated and experimental creep tests.

\subsection{Analysis of Variance}

All of the results are expressed in terms of the mean \pm the standard deviation (SD). The significance of the differences was calculated using Scheffe's test; $p<0.05$ was considered to be significant. 


\section{Results and Discussion}

\subsection{Physical and Flexural Properties}

The physical properties of the studied untreated and heat-treated bamboo samples are shown in Table 1, including the density $(\rho)$ and moisture content $(M C)$. The density significantly decreased from $721\left(\mathrm{MO}_{\mathrm{NT}}\right)$ to $642 \mathrm{~g} / \mathrm{cm}^{3}$ when the heat treatment temperature increased to $220^{\circ} \mathrm{C}$. The results showed that the density loss rate $(D L R)$ was $4.0 \%$ when the bamboo sample was heated at $180^{\circ} \mathrm{C}\left(\mathrm{MO}_{\mathrm{T} 180}\right)$. This phenomenon is related to the mass loss of the heat-treated sample due to the thermal degradation of chemical components, such as hemicellulose and extractives $[3,8,10,22]$. Furthermore, the $D L R$ value significantly increased to $10.8 \%$ with heat treatment at $220{ }^{\circ} \mathrm{C}\left(\mathrm{MO}_{\mathrm{T} 220}\right)$, which indicated that the decrease in the $\rho$ value for $\mathrm{MO}_{\mathrm{T} 220}$ was higher than that for $\mathrm{MO}_{\mathrm{T} 180}$. This is attributed to the considerable decomposition of the noncrystalline cellulose and hemicellulose $[3,8,10,22]$. Additionally, the moisture content $(M C)$ significantly decreased from $8.9 \%\left(\mathrm{MO}_{\mathrm{NT}}\right)$ to $6.0 \%$, and $5.0 \%$ for $\mathrm{MO}_{\mathrm{T} 180}$ and $\mathrm{MO}_{\mathrm{T} 220}$, respectively. This result revealed that the $M C$ value of the bamboo samples decreased as the heat treatment temperature increased. $\mathrm{MO}_{\mathrm{NT}}$ exhibited the highest $M C$ value among all the samples since the bamboo is sensitive to moisture. However, the loss rate of the $M C$ value $(M L R)$ was $33.5 \%$ for $\mathrm{MO}_{\mathrm{T} 180}$ and $44.9 \%$ for $\mathrm{MO}_{\mathrm{T} 220}$. Yang et al. [8] and Salim et al. [23] reported that the $M L R$ value of bamboo decreased due to a decreasing hygroscopy with increasing heat treatment temperature. In view of these results, heat treatment could have modified the bamboo sample to become hydrophobic due to the increase in the cellulosic crystallinity and hemicellulose degradation [24,25]. Additionally, the decrease in the hygroscopicity of the heat-treated bamboo is related to the hornification effect, which is the consequence of irreversible hydrogen bonding during heat treatment [26]. The flexural properties of all the samples are presented in Table 1. Mo NT $_{1}$ exhibited flexural properties with MOR, MOE, and $\varepsilon_{\mathrm{u}}$ values of $135 \mathrm{MPa}, 10.8 \mathrm{GPa}$, and $2.9 \%$, respectively. MOR and $\varepsilon_{\mathrm{u}}$ significantly decreased by $32.6 \%$ and $62.1 \%$, respectively, when the samples were thermally treated at $220^{\circ} \mathrm{C}$. Previous studies have indicated that the mechanical properties of bamboo were reduced at higher treatment temperatures [8,9]. However, there was no significant difference in the MOE among all the samples, which remained in the range of 10.8 to $11.6 \mathrm{GPa}$. Similar results were reported by Yang et al. [8] and Manalo and Acda [27]. The decline in the mechanical properties of the heat-treated bamboo samples could be related to the depolymerization of hemicellulose and cellulose and the separation of the hemicellulose-lignin copolymer [28,29]. Bhuiyan and Sobue [30] found that the cellulose in wood degrades under heat treatment at $200-240{ }^{\circ} \mathrm{C}$. The results indicated that the flexural properties of the bamboo samples were considerably influenced by the heat treatment.

Table 1. Physical and flexural properties of untreated and heat-treated bamboo samples.

\begin{tabular}{|c|c|c|c|c|c|c|c|}
\hline \multirow[b]{2}{*}{ Code } & \multirow{2}{*}{$\begin{array}{c}\rho \\
\left(\mathrm{kg} / \mathrm{m}^{3}\right)\end{array}$} & \multirow{2}{*}{$\begin{array}{c}D L R \\
(\%)\end{array}$} & \multirow{2}{*}{$\begin{array}{l}M C \\
(\%)\end{array}$} & \multirow{2}{*}{$\begin{array}{c}M L R \\
(\%)\end{array}$} & \multicolumn{3}{|c|}{ Flexural Properties } \\
\hline & & & & & MOR (MPa) & MOE (GPa) & $\begin{array}{c}\mathcal{E}_{\mathbf{u}} \\
(\%)\end{array}$ \\
\hline $\mathrm{Mo}_{\mathrm{NT}}$ & $721 \pm 13^{a}$ & - & $8.9 \pm 0.2^{a}$ & - & $135 \pm 7^{a}$ & $10.8 \pm 1.1^{\mathrm{a}}$ & $2.9 \pm 0.3^{a}$ \\
\hline $\mathrm{Mo}_{\mathrm{T} 180}$ & $682 \pm 20^{b}$ & $4.0 \pm 1.0^{\mathrm{b}}$ & $6.0 \pm 0.4^{b}$ & $33.5 \pm 4.2^{b}$ & $133 \pm 7^{a}$ & $11.6 \pm 0.6^{\mathrm{a}}$ & $1.5 \pm 0.1^{b}$ \\
\hline $\mathrm{Mo}_{\mathrm{T} 220}$ & $642 \pm 19^{c}$ & $10.8 \pm 1.7^{\mathrm{a}}$ & $5.0 \pm 0.3^{c}$ & $44.9 \pm 2.6^{\mathrm{a}}$ & $91 \pm 16^{b}$ & $10.8 \pm 0.8^{a}$ & $1.1 \pm 0.3^{c}$ \\
\hline
\end{tabular}

Values are the mean $\pm \operatorname{SD}(n=8)$. Different letters within a column indicate significant differences $(p<0.05)$.

The WARs and VSCs of samples heated at different treatment temperatures after water immersion are listed in Table 2. Mo $\mathrm{N}_{\mathrm{NT}}$ had the highest WAR $(49.3 \%)$ and VSC $(10.6 \%)$ values among all the samples. This is attributed to the fact that bamboo tissue contains vessels and parenchyma cells that enable water penetration, and hydrogen bonds with water molecules are formed due to the many free hydroxyl groups in the bamboo cell wall [31,32]. By contrast, the WAR value significantly decreased to $35.2 \%$, while the heat treatment increased to $180^{\circ} \mathrm{C}$ and then leveled off at up to $220^{\circ} \mathrm{C}$. In the same way, the $A W A E$ values 
of the heat-treated samples were in the range of $28.3 \%$ to $32.4 \%$. The results showed that the WAR tended to decrease as the treatment temperature increased to $180^{\circ} \mathrm{C}$. Moreover, the statistical analysis indicated that there were no significant differences among the WAR results of the bamboo samples when the treatment temperature was more than $180{ }^{\circ} \mathrm{C}$. Furthermore, the VSC values were $7.9 \%$ and $4.5 \%$ for Мот180 and Мот220, respectively. The $A S E$ values increased from $24.1 \%$ to $56.3 \%$ with increasing treatment temperature from $180^{\circ} \mathrm{C}$ to $220^{\circ} \mathrm{C}$. According to these results, large $A W A E$ and $A S E$ values indicate better performance in reducing the water absorption and volume swelling of the bamboo during the water absorption test. Therefore, these results demonstrated that the bamboo samples heated at higher treatment temperatures had higher water resistances. These findings are mainly ascribed to the hydrolyzation of hemicelluloses during the heat treatment, which decreases the hygroscopicity of bamboo $[8,33,34]$.

Table 2. Dimensional stability of untreated and heat-treated bamboo samples after water absorption test for $24 \mathrm{~h}$.

\begin{tabular}{ccccc}
\hline \multirow{2}{*}{ Code } & \multirow{2}{*}{$\begin{array}{c}\text { WAR } \\
\text { (\%) }\end{array}$} & AWAE & VSC & $A S E$ \\
\cline { 3 - 5 } & & $\mathbf{( \% )}$ & $\mathbf{( \% )}$ & $\mathbf{( \% )}$ \\
\hline Mo $_{\mathrm{NT}}$ & $49.3 \pm 4.5^{\mathrm{a}}$ & - & $10.6 \pm 0.9^{\mathrm{a}}$ & - \\
$\mathrm{Mo}_{\mathrm{T} 180}$ & $35.2 \pm 3.4^{\mathrm{b}}$ & $28.3 \pm 7.0^{\mathrm{a}}$ & $7.9 \pm 0.9^{\mathrm{b}}$ & $24.1 \pm 9.1^{\mathrm{b}}$ \\
$\mathrm{Mo}_{\mathrm{T} 220}$ & $33.2 \pm 2.4^{\mathrm{b}}$ & $32.4 \pm 5.0^{\mathrm{a}}$ & $4.5 \pm 0.9^{\mathrm{c}}$ & $56.3 \pm 8.9^{\mathrm{a}}$ \\
\hline
\end{tabular}

Values are the mean $\pm \mathrm{SD}(n=7)$. Different letters within a column indicate significant differences $(p<0.05)$.

\subsection{Master and Predicted Curves by the SSM}

In this study, accelerated creep tests using the SSM at a range of elevated stresses were performed. As an example, Figure 2a shows the flexural creep strain of $\mathrm{Mo}_{\mathrm{NT}}$ at a reference stress of $20 \%$ ABL with a $5 \%$ stepwise increase in the ABL and a dwell time of $2 \mathrm{~h}$ over the actual time. The master curve of the SSM was constructed by the following four steps of test data adjustments: (1) vertical shifting, (2) rescaling, (3) eliminating, and (4) horizontal shifting.
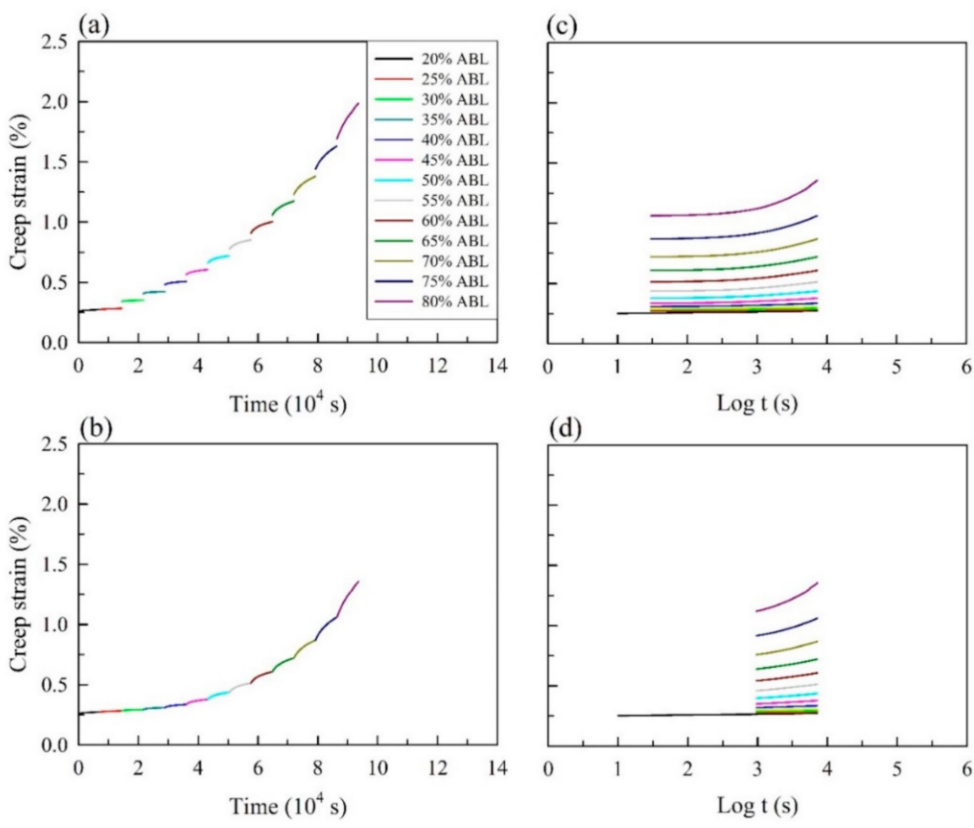

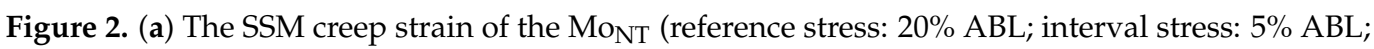
dwell time: $2 \mathrm{~h}$ ). The processing of the test data of the SSM method for MonT: (b) vertical shifting, (c) rescaled creep curves, and (d) eliminating the period before the onset time of each stress step. 
As shown in Figure $2 b$, a continuous creep strain curve was generated through vertical shifting to link the start of the current curve to the end of the previous curve at each load step. The immediate strain jumps between the load steps were subtracted by vertical shifting since there was no creep strain at each jump under instantaneous strain. According to a previous study [35], the rescaling and eliminating processes were carried out using a modified method as the first two steps in the SSM. A series of independent creep curves from stepwise sequential stress increases were shifted to the reference stress level ( $20 \% \mathrm{ABL})$ along the log scale of the time axis, as shown in Figure 2c. Additionally, the time before the onset of the primary creep region was influenced by the stress-level history, and it was eliminated from the individual curves (Figure 2d). Subsequently, the individual creep curves were horizontally shifted to construct the master curve along the time axis according to the shift factor $\log \left(\alpha_{\sigma}\right)$. Figure $3 a-c$ illustrates the smooth master curves of all the untreated and heat-treated samples obtained from different testing parameters after the SSM processing steps. Furthermore, all of the creep master curves of the untreated and heat-treated bamboo samples were fitted with each 90 days of experimental creep strain data. The results demonstrated that the creep master curves of the bamboo samples using the SSM procedure were highly consistent with the experimental data, and they were not affected by the test conditions for a given bamboo sample. Relationships between the time-stress shift factor and stress level from different SSM testing parameters are shown in Figure 3d-f. The plot of the shift factor versus the stress level exhibited a nearly straight line with a linear regression coefficient of determination $\left(R^{2}\right)$ greater than 0.90 . Previous studies have reported that the construction of master curves for various materials was not influenced by different SSM testing parameters, indicating a consistent creep mechanism [17-19,35]. Based on the Eyring model (Equation (13)), the activation volume $\left(V^{*}\right)$ of MonT was calculated from the linear slope to $0.93 \mathrm{~nm}^{3}$, while the $V^{*}$ values were $0.46 \mathrm{~nm}^{3}$ and $0.74 \mathrm{~nm}^{3}$ for $\mathrm{Mo}_{\mathrm{T} 180}$ and $\mathrm{Mo}_{\mathrm{T} 220}$, respectively. This result implied that the $V^{*}$ values of the heat-treated samples were lower than those of the untreated sample. The change in activation volume corresponded to chain slippage of crystalline lamellae in the lamellar clusters [36].
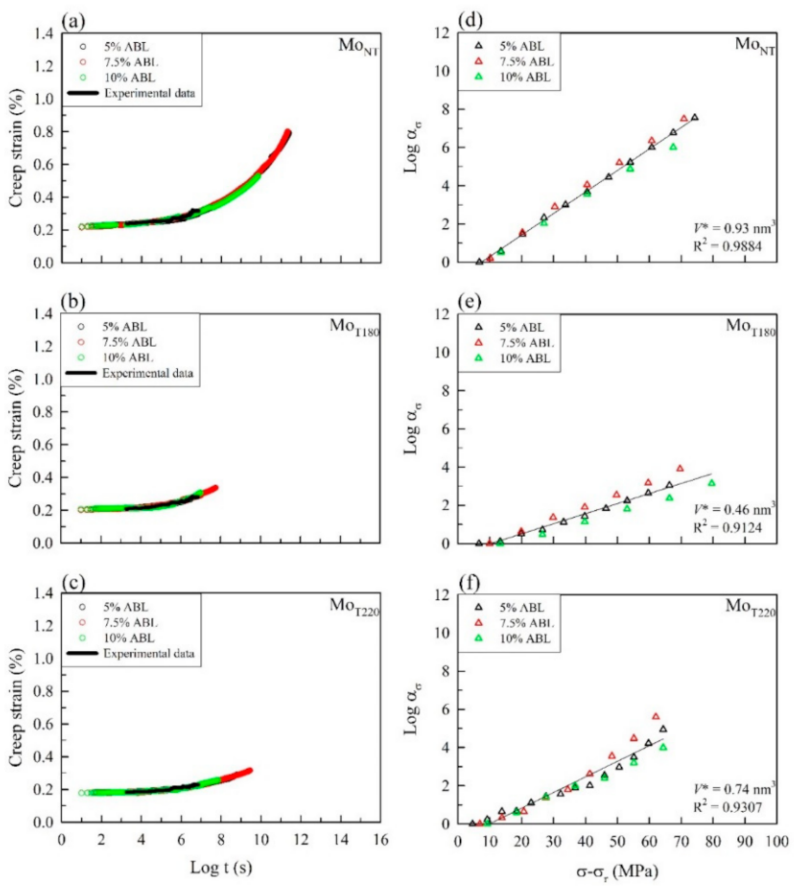

Figure 3. (a-c) Master curves after horizontal shifting from different SSM testing parameters and experimental data. (d-f) Relationships between the time-stress shift factor and stress level from different SSM testing parameters. 
On the other hand, the SSM-predicted compliance master curves of the untreated and heat-treated bamboo samples on a log time scale are shown in Figure 4a-c. An exponential growth equation with three parameters was fitted with the creep master curves of all the samples, which is given by the following equation:

$$
S(t)=S_{0}+a e^{b t}
$$

where $S(t)$ is the time-dependent compliance value, $S_{0}$ is the instantaneous elastic compliance value, $a$ and $b$ are constant values, and $t$ is the elapsed time. The model fit the master curves very well over the entire period, and the $R^{2}$ values for all the samples were greater than 0.98 (Table 3). Figure $4 \mathrm{~d}$ presents the SSM-fitted creep curves of all the samples on a normal time scale over 20 years. Accordingly, the $S_{0}$ values were 1.51, 1.49, and $1.84 \mathrm{GPa}^{-1}$ for $\mathrm{Mo}_{\mathrm{NT}}, \mathrm{Mo}_{\mathrm{T} 180}$, and $\mathrm{Mo}_{\mathrm{T} 220}$, respectively. When the heat treatment temperature increased to $180^{\circ} \mathrm{C}$, the compliance values significantly increased to 3.14 and $3.32 \mathrm{GPa}^{-1}$ at 10 and 15 years, although the results were different in the first year. However, the $\mathrm{Mo}_{\text {T220 }}$ compliance was similar to that of MonT when the sample was thermally treated at $220^{\circ} \mathrm{C}$. In addition, the $b$ values of all the heat-treated samples were higher than that of MonT (0.38). The results indicated that the heat-treated samples had a high creep rate. Furthermore, the degradation ratio of the creep resistance $\left(r_{\mathrm{d}}\right)$ was calculated to estimate the creep behavior of the heat-treated samples compared to that of $\mathrm{Mo}_{\mathrm{NT}}$ under long-term conditions, which is described by the following equation (Equation (16)):

$$
r_{\mathrm{d}}(\%)=\left[\frac{S(t)_{\mathrm{h}}}{S(t)_{\mathrm{N}}}-1\right] \times 100
$$

where $S(t)_{\mathrm{N}}$ and $S(t)_{\mathrm{h}}$ are the time-dependent compliances for the untreated and heattreated samples, respectively. As listed in Table $3, \mathrm{Mo}_{\mathrm{T} 180}$ had the highest $r_{\mathrm{d}}$ value observed in this work, and the corresponding creep resistance increasingly degraded to $5.0 \%$ and $7.2 \%$ over 10 and 15 years, respectively. Moreover, when the heat treatment temperature increased above $180{ }^{\circ} \mathrm{C}, r_{\mathrm{d}}$ could be reduced to $0.9 \%$ at 10 years and $0.3 \%$ at 15 years $\left(\mathrm{Mo}_{\mathrm{T} 220}\right)$. Accordingly, these results demonstrated that the long-term creep resistance of the tested bamboo sample would be degraded by heat treatment.
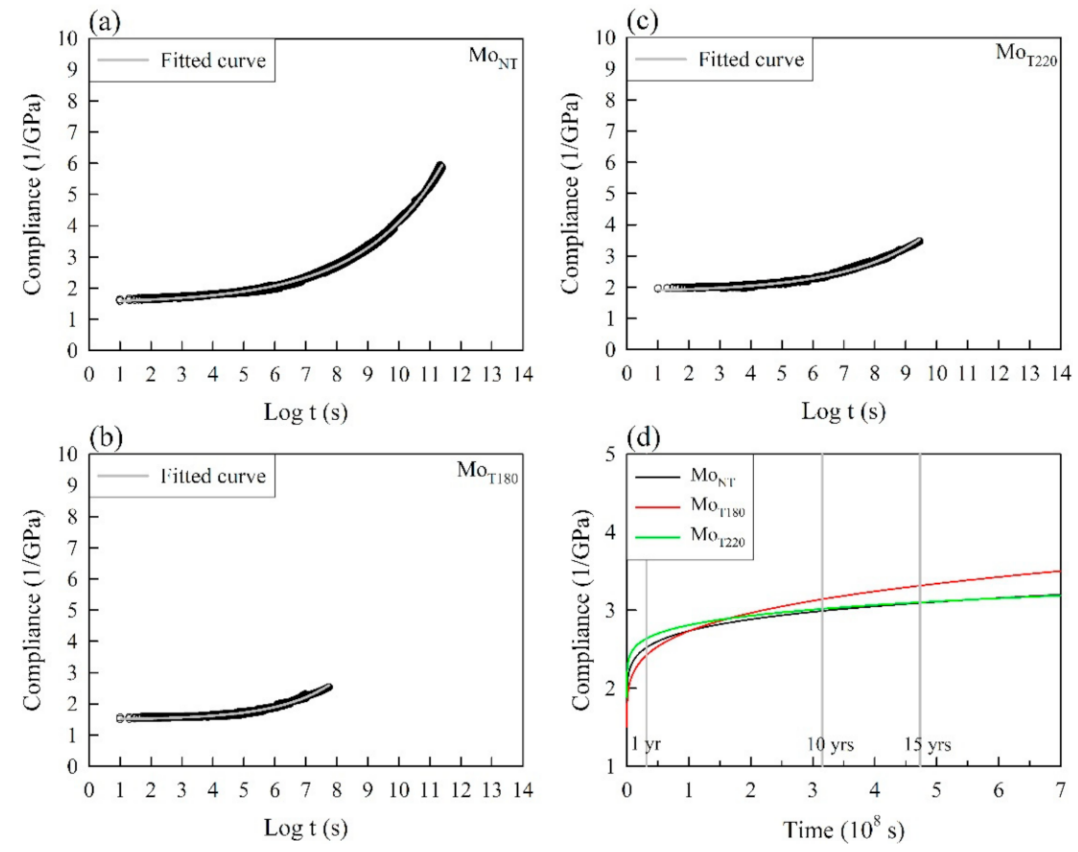

Figure 4. SSM-fitted creep curves of various samples on a log time scale (a-c) and normal time scale (d). 
Table 3. Fitted creep compliances of untreated and heat-treated bamboo samples.

\begin{tabular}{|c|c|c|c|c|c|c|c|c|c|c|}
\hline \multirow{3}{*}{ Code } & \multirow{3}{*}{$\mathrm{S}_{0}(1 / \mathrm{GPa})$} & \multirow{3}{*}{ a } & \multirow{3}{*}{ b } & \multirow{3}{*}{$\mathbf{R}^{2}$} & \multirow{2}{*}{\multicolumn{3}{|c|}{$\begin{array}{c}S(t)(1 / G P a) \\
\text { Time (Years) }\end{array}$}} & \multirow{2}{*}{\multicolumn{3}{|c|}{$\frac{R_{\mathrm{d}}(\%)}{\text { Time (Years) }}$}} \\
\hline & & & & & & & & & & \\
\hline & & & & & 1 & 10 & 15 & 1 & 10 & 15 \\
\hline $\mathrm{Mo}_{\mathrm{NT}}$ & 1.51 & $5.86 \times 10^{-2}$ & 0.38 & 0.9981 & 2.52 & 2.99 & 3.09 & - & - & - \\
\hline $\mathrm{Mo}_{\mathrm{T} 180}$ & 1.49 & $1.30 \times 10^{-2}$ & 0.57 & 0.9855 & 2.42 & 3.14 & 3.32 & -3.9 & 5.0 & 7.2 \\
\hline $\mathrm{Mo}_{\mathrm{T} 220}$ & 1.84 & $4.28 \times 10^{-2}$ & 0.39 & 0.9928 & 2.64 & 3.02 & 3.10 & 4.5 & 0.9 & 0.3 \\
\hline
\end{tabular}

$S(t)=S_{0}+a e^{b t}$, where $S(t)$ is the time-dependent compliance value, $S_{0}$ is the instantaneous elastic compliance value, and $a$ and $b$ are constant values. $r_{\mathrm{d}}$ is the degradation ratio of creep resistance.

\section{Conclusions}

The present study investigated the influence of heat treatment temperature on the physico-mechanical properties and creep behavior of moso bamboo. The results indicated that the density, moisture content, and flexural properties (MOR, MOE, and $\varepsilon_{\mathrm{u}}$ ) decreased as the heat treatment temperature was increased up to $220^{\circ} \mathrm{C}$. Additionally, heat-treated bamboo samples had higher $A W A E$ and $A S E$ values than the untreated samples according to the water absorption test results, indicating that samples heated at higher temperatures $\left(>180{ }^{\circ} \mathrm{C}\right.$ ) exhibited a better water resistance. Furthermore, the master curves for all the samples using SSM with different testing parameters fit well with the 90 days of full-scale experimental data, and the construction of master curves was not influenced by the different testing parameters. The results indicated that the SSM was suitable for constructing the master curves of bamboo samples. Based on the linear slope of the Eyring plots, the activation volumes $\left(V^{*}\right)$ of the heat-treated bamboo samples $\left(0.46 \mathrm{~nm}^{3}\right.$ for MoT180 $_{T}$ and $0.74 \mathrm{~nm}^{3}$ for $\left.\mathrm{Mo}_{\mathrm{T} 220}\right)$ were lower than that of the untreated sample $\left(0.93 \mathrm{~nm}^{3}\right)$. On the other hand, the degradation ratio of the creep resistance significantly increased over all periods when the heat treatment temperature increased to $180^{\circ} \mathrm{C}$. However, the samples treated at $220^{\circ} \mathrm{C}$ exhibited a reduction in the degradation ratio of the long-term creep resistance over time.

Author Contributions: Conceptualization, T.-C.Y.; Data curation, T.-C.Y., T.-L.W. and C.-H.Y.; Formal analysis, T.-C.Y. and T.-L.W.; Funding acquisition, T.-C.Y.; Investigation, T.-C.Y., T.-L.W. and C.H.Y.; Project administration, T.-C.Y.; Resources, T.-C.Y.; Supervision, T.-C.Y.; Validation, T.-C.Y.; Visualization, T.-C.Y., T.-L.W. and C.-H.Y.; Writing-original draft, T.-C.Y., T.-L.W. and C.-H.Y.; Writing - review and editing, T.-C.Y. All authors have read and agreed to the published version of the manuscript.

Funding: This research was funded by the Ministry of Science and Technology, Taiwan grant number (MOST 108-2313-B-005-014-MY3).

Institutional Review Board Statement: Not applicable.

Informed Consent Statement: Not applicable.

Data Availability Statement: Not applicable.

Conflicts of Interest: The authors declare no conflict of interest.

\section{References}

1. Chung, M.-J.; Wang, S.-Y. Mechanical properties of oriented bamboo scrimber boards made of Phyllostachys pubescens (moso bamboo) from Taiwan and China as a function of density. Holzforshung 2018, 72, 151-158. [CrossRef]

2. Yu, Y.; Liu, R.; Huang, X.; Meng, F.; Yu, W. Preparation, physical, mechanical, and interfacial morphological properties of engineered bamboo scrimber. Constr. Build. Mater. 2017, 157, 1032-1039. [CrossRef]

3. Yang, T.-C.; Lee, T.-Y. Effects of density and heat treatment on the physico-mechanical properties of unidirectional round bamboo stick boards (UBSBs) made of Makino bamboo (Phyllostachys makinoi). Constr. Build. Mater. 2018, 187, 406-413. [CrossRef]

4. Verma, C.S.; Chariar, V.M. Development of layered laminate bamboo composite and their mechanical properties. Compos. Part B Eng. 2012, 43, 1063-1069. [CrossRef] 
5. Lee, C.H.; Chung, M.J.; Lin, C.H.; Yang, T.H. Effects of layered structure on the physical and mechanical properties of laminated moso bamboo (Phyllosachys edulis) flooring. Constr. Build. Mater. 2012, 28, 31-35. [CrossRef]

6. Lee, S.-H.; Wang, S. Biodegradable polymers/bamboo fiber biocomposite with bio-based coupling agent. Compos. Part A Appl. Sci. Manuf. 2006, 37, 80-91. [CrossRef]

7. Yang, T.-C.; Wu, T.-L.; Hung, K.-C.; Chen, Y.-L.; Wu, J.-H. Mechanical properties and extended creep behavior of bamboo fiber reinforced recycled poly(lactic acid) composites using the time-temperature superposition principle. Constr. Build. Mater. 2015, 93, 558-563. [CrossRef]

8. Yang, T.-H.; Lee, C.-H.; Lee, C.-J.; Cheng, Y.-W. Effects of different thermal modification media on physical and mechanical properties of moso bamboo. Constr. Build. Mater. 2016, 119, 251-259. [CrossRef]

9. Zhang, Y.; Yu, Y.; Yu, W. Effect of thermal treatment on the physical and mechanical properties of Phyllostachys pubescen bamboo. Eur. J. Wood Wood Prod. 2013, 71, 61-67. [CrossRef]

10. Yang, T.-C.; Yang, Y.-H.; Yeh, C.-H. Thermal decomposition behavior of thin Makino bamboo (Phyllostachys makinoi) slivers under nitrogen atmosphere. Mater. Today Commun. 2021, 26, 102054. [CrossRef]

11. Chung, M.J.; Wang, S.Y. Effects of peeling and steam-heating treatment on basic properties of two types of bamboo culms (Phyllostachys makinoi and Phyllostachys pubescens). J. Wood Sci. 2017, 63, 473-482. [CrossRef]

12. Marasigan, O.S.; Razal, R.A.; Alipon, M.A. Effect of thermal treatment on the wettability of giant bamboo (Dendrocalamus asper) and kawayan tinik (Bambusa blumeana) in the Philippines. J Trop. For. Sci. 2020, 32, 369-378. [CrossRef]

13. Brito, F.M.S.; Paes, J.B.; Oliveira, J.T.D.; Arantes, M.D.C.; Dudecki, L. Chemical characterization and biological resistance of thermally treated bamboo. Constr. Build. Mater. 2020, 262, 120033. [CrossRef]

14. Kanzawa, E.; Aoyagi, S.; Nakano, T. Vascular bundle shape in cross-section and relaxation properties of Moso bamboo (Phyllostachys pubescens). Mater. Sci. Eng. C 2011, 31, 1050-1054. [CrossRef]

15. Tsubaki, T.; Nakano, T. Creep behavior of bamboo under various desorption conditions. Holzforschung 2010, 64, 489-493. [CrossRef]

16. Gottron, J.; Harries, K.A.; Xu, Q. Creep behavior of bamboo. Constr. Build. Mater. 2016, 119, 251-259. [CrossRef]

17. Huang, C.-W.; Yang, T.-C.; Wu, T.-L.; Hung, K.-C.; Wu, J.-H. Effects of maleated polypropylene content on the extended creep behavior of wood polypropylene composites using the stepped isothermal method and the stepped isostress method. Wood Sci. Technol. 2018, 52, 1313-1330. [CrossRef]

18. Hung, K.-C.; Wu, T.-L.; Wu, J.-H. Long-term creep behavior prediction of sol-gel derived $\mathrm{SiO}_{2}$ - and $\mathrm{TiO}_{2}$-wood composites using the stepped isostress method. Polymers 2019, 11, 1215. [CrossRef]

19. Giannopoulos, I.P.; Burgoyne, C.J. Accelerated and real-time creep and creep-rupture results for aramid fibers. J. Appl. Polym. Sci. 2012, 125, 3856-3870. [CrossRef]

20. Hadid, M.; Guerira, B.; Bahri, M.; Zouani, A. Assessment of the stepped isostress method in the prediction of long term creep of thermoplastics. Polym. Test. 2014, 34, 113-119. [CrossRef]

21. Chevali, V.S.; Dean, D.R.; Janowski, G.M. Flexural creep behavior of discontinuous thermoplastic composites: Non-linear viscoelastic modeling and time-temperature-stress superposition. Compos. Part A Appl. Sci. 2009, 40, 870-877. [CrossRef]

22. Lee, C.-H.; Yang, T.-H.; Cheng, Y.-W.; Lee, C.-J. Effects of thermal modification on the surface and chemical properties of moso bamboo. Constr. Build. Mater. 2018, 178, 59-71. [CrossRef]

23. Salim, R.; Ashaari, Z.; Samsi, H.W.; Wahab, R.; Alamjuri, R.H. Effect of oil heat treatment on physical properties of Semantan bamboo. Mod. Appl. Sci. 2010, 4, 107-113. [CrossRef]

24. Windeisen, E.; Bächle, H.; Zimmer, B.; Wegener, G. Relations between chemical changes and mechanical properties of thermally treated wood. Holzforschung 2009, 63, 773-778. [CrossRef]

25. Tumuluru, J.S.; Sokhansanj, S.; Hess, J.R.; Wright, C.T.; Boardman, R.D. A review on biomass torrefaction process and product properties for energy applications. Ind. Biotechnol. 2011, 7, 384-401. [CrossRef]

26. Borrega, M.; Kärenlampi, P.P. Hygroscopicity of heat-treated Norway spruce (Picea abies) wood. Eur. J. Wood Prod. 2010, 68, 233-235. [CrossRef]

27. Manalo, R.; Acda, M. Effects of hot oil treatment on physical and mechanical properties of three species of Philippine bamboo. J. Trop. For. Sci. 2009, 21, 19-24. Available online: https://www.jstor.org/stable/23616558?seq=1\#metadata_info_tab_contents (accessed on 23 February 2020).

28. Garrote, G.; Dominiguez, H.; Parajo, J.C. Study on the deactylation of hemicelluloses during the hydrothermal processing of Eucalyptus wood. Holz. Roh. Werkst. 2001, 59, 53-59. [CrossRef]

29. Çolak, S.; Çolakoğlu, G.; Aydin, I.; Kalaycioğlu, H. Effects of steaming process on some properties of eucalyptus particleboard bonded with UF and MUF adhesives. Build. Environ. 2007, 42, 304-309. [CrossRef]

30. Bhuiyan, M.T.R.; Sobue, N.H.N. Changes of crystallinity in wood cellulose by heat treatment under dried and moist conditions. J. Wood Sci. 2000, 46, 431-436. [CrossRef]

31. Abdullah, C.K.; Jawaid, M.; Abdul Khalil, H.P.S.; Zaidon, A.; Hadiyane, A. Oil palm trunk polymer composite: Morphology, water absorption, and thickness swelling behaviors. BioResources 2012, 7, 2948-2959. Available online: https://ojs.cnr. ncsu.edu/index.php/BioRes/article/view/BioRes_07_3_2948_Abdullah_JKZH_Palm_Trunk_Polymer_Composite (accessed on 23 February 2020). 
32. Abdul Khalil, H.P.S.; Bhata, I.U.H.; Jawaid, M.; Zaidon, A.; Hermawan, D.; Hadi, Y.S. Bamboo fibre reinforced biocomposites: A review. Mater. Des. 2012, 42, 353-368. [CrossRef]

33. Ayrilmis, N.; Jarusombuti, S.; Fueangvivat, V.; Bauchongkol, P. Effect of thermal-treatment of wood fibres on properties of flat-pressed wood plastic composites. Polym. Degrad. Stab. 2011, 96, 818-822. [CrossRef]

34. Winandy, J.E.; Krzysik, A. Thermal degradation of wood fibres during hot-pressing of MDF composites: Part I. Relative effects and benefits of thermal exposure. Wood Fiber. Sci. 2007, 39, 450-461. Available online: https://www.fs.usda.gov/treesearch/ pubs / 29254 (accessed on 23 February 2020).

35. Yeo, S.S.; Hsuan, Y.G. Predicting the creep behavior of high density polyethylene geogrid using stepped isothermal method. In Service Life Prediction of Polymeric Materials: Global Perspectives; Martin, J.W., Ryntz, R.A., Chin, J., Dickie, R.A., Eds.; Springer: New York, NY, USA, 2009; pp. 205-218.

36. Gao, R.; Kuriyagawa, M.; Nitta, K.-H.; He, X.; Liu, B. Structural interpretation of Eyring activation parameters for tensile yielding behavior of isotactic polypropylene solids. J. Macromol. Sci. B 2015, 54, 1196-1210. [CrossRef] 